\title{
Preterm Birth
}

National Cancer Institute

\section{Source}

National Cancer Institute. Preterm Birth. NCI Thesaurus. Code C92861.

Birth when a fetus is less than 37 weeks and 0 days gestational age. 